\title{
ACCESS TO FORMAL BANKING SERVICES IN THE SADC, 2000-2009
}

\author{
Andrie Schoombee* \\ Stellenbosch University \\ gas2@sun.ac.za
}

Received: June 2012

Accepted: August 2014

\begin{abstract}
Access to basic financial services is one possible path leading to a better life for the poor. This is endorsed by SADC governments, and various strategies were in the past decade implemented to advance financial access. South Africa was particularly successful in enhancing access via its government-incentivised Mzansi entry-level bank account. This study researches what happened in the other SADC countries and specifically the role governments played in lifting the barriers to access to and use of formal banking services. It is concluded that no other SADC country was as successful as South Africa.
\end{abstract}

Keywords

Financial access, formal banking services, SADC

*Prof A Schoombee is a professor in the Department of Economics, Stellenbosch University, Stellenbosch, South Africa. 


\section{INTRODUCTION}

The Southern African Development Community (SADC), comprising 15 member countries of which nearly $50 \%$ were classified as low-income countries in 2009 (World Bank, 2011), views the alleviation of poverty as its foremost priority in the economic integration process (SADC, 2008). Access to basic financial services is widely recognised as one possible means to achieve a better life for the poor (see for example Caskey, Durán \& Solo, 2006, and Dupas \& Robinson, 2009). This is also the case in the SADC, where currently more than $50 \%$ of its members claim to have a strategy document for the advancement of financial access (CGAP \& World Bank, 2010: Table 6).

One of the SADC's member countries, South Africa, has in the previous decade succeeded in substantially increasing the use of formal banking services, especially by the poor. Between 2004 and 2008, the increase in use of banking services by the poor was in the order of $45 \%$, and the main contributor was found to be support for the government-incentivised Mzansi entry-level bank account offered by private banks and the government-owned Postbank (Schoombee, 2009:136).

The focus of this paper is on what transpired in the other SADC countries with regard to access to and use of formal banking products in the period 2000 to 2009, and specifically governments' policies to encourage this, in order to determine if similar successes to that in South Africa were achieved elsewhere and what the role of policy was. Data on the levels of access to and use of formal banking services in the latter stages of the period of study will be presented, as well as changes thereto over the period. Unfortunately the availability of comparative data is a problem in many instances (the Seychelles is a case in point and was consequently excluded from most of the discussion), and this precludes any definitive conclusions. Nevertheless, the identification of the major barriers to access and use and consideration of the role and policies of SADC governments to lift these barriers will not only reveal where the focus of policy was, but should also provide pointers to where governments should concentrate their efforts in future.

The data used in this study was compiled from published research and qualitatively interpreted by the author. Compiling data to measure access to and use of financial services is challenging, especially in low- and middle-income countries where data capturing in the formal financial sector is not on par with that in industrialised economies. Fortunately FinMark Trust commenced its FinScope surveys of a representative sample of individual users of financial services in a number of African countries in 2003, including seven of the fifteen SADC countries. These surveys are "... a tool to assess financial access in any particular country and to identify the constraints that prevent financial markets from reaching out to poorer consumers" (FinMark Trust, 2009b: 13), and the standardised methodology in principle allows comparison between countries. There are, however, limitations to this methodology that also impact on the comparability of the results (e.g. some questions can be regarded as intrusive and thus may have a bearing on the reliability of the responses, questions are not necessarily precisely the same for each country). Honohan and King (2009: 4-10) discuss these limitations.

\section{BANKING IN SADC: ACCESS, USE AND BARRIERS}

The four SADC countries that are the most banked according to all three criteria measuring the use of banking services in TABLE I (Botswana, Mauritius, Namibia and South Africa), are also the countries with the greatest access to banking services. This is to be expected, and is also in line 
with the findings of a financial access survey of 142 economies that there is a positive correlation between branch penetration and deposit account penetration as well as branch penetration and loan account penetration (CGAP et al., 2010:7,10). These countries also represent four of the five higher-middle-income members of the SADC, the other being the Seychelles, for which no data is available, and given their level of development would be expected to be the most banked.

TABLE 1: Measures of access to and use of banking services

\begin{tabular}{|c|c|c|c|c|c|c|c|}
\hline & & & Access & & & Use & \\
\hline Country & year & $\begin{array}{c}5 \\
5 \\
5 \\
2 \\
\frac{1}{2} \\
0 \\
0 \\
\frac{1}{2}\end{array}$ & 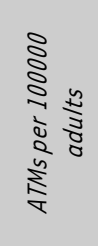 & 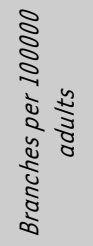 & 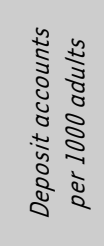 & 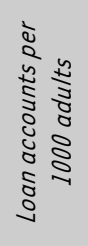 & 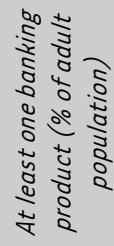 \\
\hline Angola & 2008 & & & 5.5 & & & \\
\hline Botswana & 2009 & 0.5 & 21.5 & 8.0 & 479 & 212 & 41 \\
\hline DRC & 2008 & & & 0.3 & 6 & & \\
\hline Lesotho & 2009 & 2.7 & 6.7 & 2.1 & 254 & 39 & \\
\hline Madagascar & 2008 & & & 1.0 & 34 & 21 & \\
\hline Malawi & 2009 & 2.2 & 2.7 & 2.2 & 163 & 17 & $19 *$ \\
\hline Mauritius & 2009 & 187.7 & 39.1 & 20.1 & 2109 & 479 & \\
\hline Mozambique & 2009 & 0.8 & 5.1 & 2.9 & 141 & & 11.8 \\
\hline Namibia & 2009 & 0.5 & 30.5 & 7.3 & 758 & 210 & $45.3 * \star$ \\
\hline South Africa & 2009 & 14.6 & 52.4 & 8.0 & 839 & & 60 \\
\hline Swaziland & 2009 & 7.6 & 18.7 & 2.9 & 236 & 70 & \\
\hline Tanzania & 2009 & 0.9 & 3.4 & 1.8 & & & 8.7 \\
\hline Zambia & 2009 & 0.6 & 6.4 & 3.6 & 28 & 18 & 13.9 \\
\hline Zimbabwe & 2009 & 1.5 & 7.8 & 6.3 & 144 & 21 & \\
\hline
\end{tabular}

Sources: FinMark Trust, FinScope surveys of relevant SADC countries, various issues; CGAP et al., 2009 \& 2010.

* 2008

** 2007

Limited data is available to form an opinion on the change in access to and use of banking services in the SADC over the past decade (see TABLE 2). Nevertheless, for the seven countries with data on the number of ATMs (automated teller machines) per $1000 \mathrm{~km}^{2}$, increases of between 25 and $800 \%$ were experienced, though mostly from a very low base (less than one ATM per $\left.1000 \mathrm{~km}^{2}\right)$. South Africa and Mauritius are the exceptions, the former recording $125 \%$ growth from a moderate base $\left(6.5\right.$ ATMs per $\left.1000 \mathrm{~km}^{2}\right)$ and the latter $41 \%$ growth from a high base (more than 100 ATMs per $1000 \mathrm{~km}^{2}$ ). It is to be expected that these significant increases in the 
availability of ATMs will have had a positive impact on being banked (closer proximity of bank access points to customers lowers travelling and opportunity cost).

TABLE 2: Changes in access to and use of banking services

\begin{tabular}{|c|c|c|c|}
\hline \multirow[b]{2}{*}{ Country } & \multirow[b]{2}{*}{ year } & Access & \multirow{2}{*}{$\begin{array}{c}\text { Use } \\
\text { At least one banking } \\
\text { product (\% of adult } \\
\text { population) }\end{array}$} \\
\hline & & ATMs per $1000 \mathrm{~km}^{2}$ & \\
\hline \multirow[t]{2}{*}{ Botswana } & $2003 / 4$ & 0.3 & \\
\hline & 2009 & 0.5 & \\
\hline \multirow[t]{2}{*}{ Mauritius } & $2003 / 4$ & 133.0 & \\
\hline & 2009 & 187.7 & \\
\hline \multirow[t]{2}{*}{ Namibia } & $2003 / 4$ & 0.3 & \\
\hline & 2009 & 0.5 & \\
\hline \multirow[t]{3}{*}{ South Africa } & $2003 / 4$ & 6.5 & \\
\hline & 2004 & & 45 \\
\hline & 2009 & 14.6 & 60 \\
\hline \multirow[t]{3}{*}{ Tanzania } & $2003 / 4$ & 0.1 & \\
\hline & 2006 & & 7.2 \\
\hline & 2009 & 0.9 & 8.7 \\
\hline \multirow[t]{3}{*}{ Zambia } & $2003 / 4$ & 0.1 & \\
\hline & 2005 & & 14.6 \\
\hline & 2009 & 0.6 & 13.9 \\
\hline \multirow[t]{2}{*}{ Zimbabwe } & 2003/4 & 1.2 & \\
\hline & 2009 & 1.5 & \\
\hline
\end{tabular}

Sources: FinMark Trust, FinScope surveys of relevant SADC countries, various issues; CGAP et al., 2010; Beck et al., 2007.

Data on changes in the use of banking services is available only for three member countries. In South Africa, the use of banking services increased by 33\% between 2004 and 2009 (but by $45 \%$ for the poor between 2004 and 2008). An annual increase was experienced until 2008, followed by a decrease in the use of banking services in 2009, but once again resuming its positive growth trend in 2010 to the extent that the percentage of the banked adult population in 2010 (63\%) reached the same level as before the once-off decrease. The decline in 2009 was attributed to the global recession that followed the global financial crisis of 2008/9 (FinMark Trust, 2010:10). In Tanzania, the percentage of the adult population that was banked increased by $21 \%$ between 2006 and 2009, whereas in Zambia it decreased by 5\% between 2005 and 2009. The cause of the decline in Zambia is in all probability linked to the global recession in 2009 , thus similar to South Africa's experience. If the global recession had a similar impact in Tanzania, and there is no 
reason to suspect otherwise, its underlying growth rate in bank usage could be a couple of percentage points above the reported $21 \%$. This would imply a substantial increase. Though not directly comparable to the growth experienced in South Africa, Tanzania's growth was realised over a considerably shorter period of time, but from a far lower base.

An analysis of the barriers to banking access as expressed by the unbanked (see TABLE 3 ) shows that a lack of employment and lack of a regular income were without doubt, and as could reasonably be expected for any country in the world, the greatest barriers in all member countries. This also ties in with a cross-country analysis of 139 countries that reveals a positive correlation between per capita income and deposit account and loan account penetration respectively (CGAP \& World Bank, 2009). This cross-country analysis also points to other possible barriers to access, including a low population density, inadequate branch penetration, insufficient physical infrastructure, an unsatisfactory legal environment (e.g. lack of legal rights including lack of property rights, lack of proper contract enforcement), and inadequate competition in the banking sector. With regard to insufficient infrastructure, a recent study of bank access in more than a hundred countries (Kendall, Mylenko \& Ponce, 2010) found that, controlling for income and population density, the level of development of physical infrastructure was the most important explanatory variable of deposit account, loan account and branch penetration.

It is important to note that the inadequate competition barrier would also contribute to three of the barriers identified by the unbanked in TABLE 3, i.e. fees are too high, the minimum amount required to open or maintain an account is too high, and the bank (an access point to the bank account) is too distant. The importance of the lack of competition is illustrated by the fact that in five of the seven SADC countries for which data is available (Malawi, Mozambique, Namibia, Tanzania and Zambia, see TABLE 3 ), one of the three barriers in question is the most significant of all the remaining barriers (thus excluding lack of employment/regular income).

TABLES 4 and 5 provide more detail on barriers to banking in six SADC economies, specifically with regard to consumer loan and deposit account access. Both these tables reflect that, throughout, access barriers in South Africa were the lowest or equal to the lowest in respect of consumer loans, and lowest or equal to the lowest in the majority of the barriers to cheque and savings account access. As the most banked economy in the SADC, this is to be expected, but it could also be presumed that this reflects a higher level of competition in South Africa than in the other countries. Reflecting on an indicator of the level of competitiveness in these six countries, it appears not to be the case. The bank concentration ratio (assets of the largest three banks as share of assets of all commercial banks) in 2004, the same year for the access barriers identified in TABLES 4 and 5, was lower in all six countries than South Africa's 0.94 (World Bank Financial Structure Database, 2009).

\section{GOVERNMENT POLICIES TO LIFT BARRIERS TO BANKING}

The main barriers to access to and use of banking services as identified by the unbanked in the SADC as well as by CGAP et al. (2009) in their extensive cross-country analysis were considered in the previous section. The focus now shifts to the role SADC governments have played in attempting to lift these barriers. 

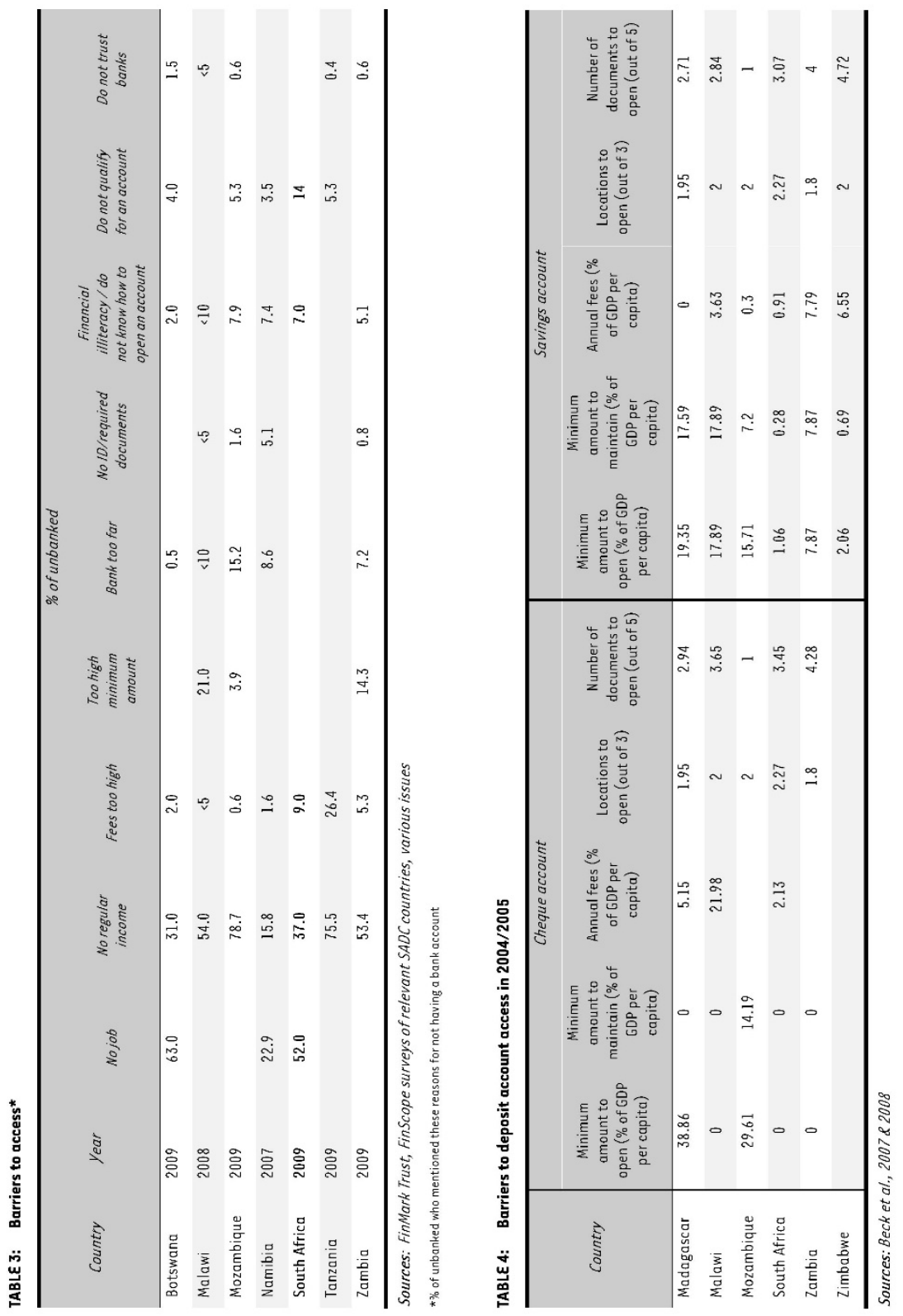
TABLE 5: Barriers to consumer loan access in 2004/2005

\begin{tabular}{lrcrr}
\hline \multicolumn{1}{c}{ Country } & $\begin{array}{c}\text { Locations to } \\
\text { submit } \\
\text { application (out } \\
\text { of 5) }\end{array}$ & $\begin{array}{c}\text { Minimum amount (\% } \\
\text { of GDP/capita) }\end{array}$ & $\begin{array}{c}\text { Fees (\% of } \\
\text { GDP/capita) }\end{array}$ & $\begin{array}{c}\text { Days to process } \\
\text { applications }\end{array}$ \\
\hline Madagascar & 2.16 & 24.06 & 2.62 & 8.55 \\
Malawi & 2.12 & 222.36 & 1 & 8.72 \\
Mozambique & 2.15 & 30.71 & 0.48 & 1.46 \\
South Africa & 5 & 7.27 & & 3.05 \\
\hline Zambia & 2 & 24.08 & & 1.46 \\
\hline Zimbabwe & 2.85 & & & \\
\hline
\end{tabular}

Source: Beck et al., $2007 \& 2008$

Governments may view failure of access and use of banking services as inherent to the market, needing direct state intervention to rectify it. Various remedies in this regard have been experimented with internationally over the past fifty years, including directing credit to worthy causes/sectors by forcing compliance from private financial institutions or establishing government-owned institutions for this specific purpose, and placing interest rate ceilings on loans to ensure affordable access.

Though there is widespread consensus internationally that direct state intervention has generally been a failure (see for example Beck, 2006; Beck \& Brown, 2011), there were SADC members that boasted some elements of this approach in their search for universal access to formal financial services. At least five SADC countries (Botswana, Malawi, Swaziland, Tanzania and Zambia) had government-owned commercial banks in the past decade and at least four had interest rate ceilings and/or banking fee limits determined by government (see TABLE 6). Furthermore, government-owned post offices were extensively used throughout the world to provide banking services. The 2009 financial access survey indicated this to have been the case in more than $70 \%$ of the 142 countries surveyed (CGAP et al., 2009:47). This was also the situation in Lesotho, Namibia and South Africa.

TABLE 6: Government policies and regulations impacting on bank access and use, 2009

\begin{tabular}{|c|c|c|c|c|c|c|}
\hline Country & $\begin{array}{l}\text { Maximum } \\
\text { rate \&/or } \\
\text { fee limits }\end{array}$ & $\begin{array}{l}\text { Effective } \\
\text { interest } \\
\text { rate } 8 / \text { or } \\
\text { fees } \\
\text { disclosed }\end{array}$ & $\begin{array}{l}\text { Plain } \\
\text { language } \\
\text { require- } \\
\text { ment }\end{array}$ & $\begin{array}{c}\text { Financial } \\
\text { literacy } \\
\text { reforms }\end{array}$ & $\begin{array}{l}\text { Basic bank } \\
\text { account: a } \\
\text { requirement } \\
\text { or reforms to } \\
\text { introduce }\end{array}$ & $\begin{array}{c}\text { Government } \\
\text { transfers to } \\
\text { deposit } \\
\text { accounts: } \\
\text { encouraged } \\
\text { or reforms } \\
\text { to } \\
\text { encourage }\end{array}$ \\
\hline Angola & & & & & & $x$ \\
\hline Botswana & & $x$ & $x$ & $x$ & & $x$ \\
\hline DRC & & $x$ & & & & \\
\hline
\end{tabular}




\begin{tabular}{|c|c|c|c|c|c|c|}
\hline Country & $\begin{array}{l}\text { Maximum } \\
\text { rate \&/or } \\
\text { fee limits }\end{array}$ & $\begin{array}{l}\text { Effective } \\
\text { interest } \\
\text { rate } 8 / \text { or } \\
\text { fees } \\
\text { disclosed }\end{array}$ & $\begin{array}{l}\text { Plain } \\
\text { language } \\
\text { require- } \\
\text { ment }\end{array}$ & $\begin{array}{c}\text { Financial } \\
\text { literacy } \\
\text { reforms }\end{array}$ & $\begin{array}{l}\text { Basic bank } \\
\text { account: a } \\
\text { requirement } \\
\text { or reforms to } \\
\text { introduce }\end{array}$ & $\begin{array}{c}\text { Government } \\
\text { transfers to } \\
\text { deposit } \\
\text { accounts: } \\
\text { encouraged } \\
\text { or reforms } \\
\text { to } \\
\text { encourage }\end{array}$ \\
\hline Lesotho & & & & $x$ & & $x$ \\
\hline Madagascar & & & & & & $x$ \\
\hline Malawi & & & & $x$ & & \\
\hline Mauritius & & $x$ & $x$ & & & \\
\hline Mozambique & & $x$ & $x$ & & $x$ & \\
\hline Namibia & $x$ & $x$ & $x$ & $x$ & $x$ & $x$ \\
\hline South Africa & $x$ & $x$ & $x$ & & $x^{\star}$ & \\
\hline Swaziland & $x$ & $x$ & & & & $x$ \\
\hline Tanzania & & $x$ & & $x$ & & $x$ \\
\hline Zambia & & $x$ & $x$ & $x$ & & \\
\hline Zimbabwe & $x$ & $x$ & $x$ & & $x$ & $x$ \\
\hline *Moral suasion & & & & & & \\
\hline
\end{tabular}

Sources: CGAP et al. 2009 \& 2010; BoN 2010; FinMark Trust 2009d; FSDT 2009

The perspective that has gained considerable ground since the early 1970 s is that governments need only create an enabling environment and provide incentives for the financial sector to flourish. Governments' actions in this regard would include, for example, ensuring a stable macroeconomic environment, ensuring a competitive milieu, and incentivising financial institutions to undertake high-cost business like lending to the poor by providing guarantees for possible loan default. Recent research, however, raises important questions in this regard. In a study of 29 transition economies, Beck et al. (2011) have found that although governments' investment in financial infrastructure and their promotion of competition has as expected broadened access to banks, it did not necessarily assist the disadvantaged. More specifically, higher deposit insurance coverage, broader physical presence (more automated teller machines, points of sale terminals and branches), and access to credit information via credit bureaus or registries did not chiefly benefit the poor. Furthermore, promoting competition in the banking sector (to lower costs to consumers and incentivise the development of services and products in demand by low-income individuals) by encouraging foreign banks to enter domestic markets was more advantageous to higher- than lower-income individuals. The conclusion reached by these authors is that market-friendly policies to increase access to banking for the poor require re-examination, as it is often not possible to direct such policies adequately to the intended beneficiaries.

The applicability of this conclusion to the whole of the SADC region is questionable. While only $10 \%$ of the transition economies in question are classified as low-income, the situation is markedly different in the SADC, with nearly $50 \%$ of its members representing low-income 
countries. Whereas governments' policies to open up access to banking for the poor may chiefly benefit the non-poor in middle-income and high-income economies, as was found in the research referred to above, this is not expected to be the case in low-income countries where poverty is endemic and the majority of the population does not have access to formal banking.

Given the barriers to banking identified in the previous section and also those highlighted by the International Monetary Fund (IMF) in its interaction with member countries (see below), SADC governments' policies to address these are explored. Seven SADC countries (Lesotho, Namibia, Malawi, Mozambique, South Africa, Tanzania and Zambia) had explicit government initiatives to boost access to banking. Botswana, although requested by the IMF to prioritise access to financial services via the privatisation of and/or restructuring of government-owned financial institutions (IMF, 2008a:17), appears not to have heeded this call.

\subsection{Physical infrastructure}

Given the low level of development of SADC economies in general and, accordingly, the expected physical infrastructure problems, especially in rural areas, it comes as no surprise that inadequate physical infrastructure was specifically identified as an impediment to banking access in Lesotho (IMF, 2004:33), Mozambique (IMF, 2010b:14), Tanzania (Khijjah, 2004) and Zambia (MFNP, 2004:64). In Tanzania's case, infrastructure spending in rural areas in order to improve the rural population's access to financial services was already part of ongoing financial sector reforms in the early 2000s and identified by the Ministry of Finance (Khijjah, 2004: 9) as a continuing focus for the rest of the decade. Notwithstanding this, it was still identified as a barrier to entry for financial institutions in 2006 (FSDT, 2006:99).

\subsection{Affordability of banking services}

Affordability of banking services is a key determinant of the poor's use of such services and reflects on the poor's level of income as well as the cost of banking services. In the discussion above on the barriers to access, both lack of income and high cost (minimum amount to open and maintain account, fees and interest rates, and distance to a bank) were emphasised by the unbanked. The poor, per definition, will always have limited income irrespective of the level of success of governments in improving their plight. Therefore governments' focus in making banking affordable should be to keep costs in check. Attempting to achieve the latter, governments can intervene directly (e.g. place ceilings on bank fees and/or lending rates, establish government-owned banks that provide services at reasonable cost to consumers), as was noted earlier to be the state of affairs in certain SADC members. Governments may also consider measures to reduce their own impact on the high costs banks experience, provide a competitive environment and/or incentivise banks to price services at an affordable level for poor customers.

The high and interest-free statutory reserve requirement for Zambian banks was identified by the Zambian Ministry of Finance and National Planning (MFNP, 2004:64) as an important contributor to high banking costs, and the ministry recommended lowering it. No indication could be found that this recommendation was implemented, however.

The level of competition, as measured by the assets of the three largest banks as share of assets of all commercial banks (see TABLE 7), leaves much to be desired in most SADC countries. In 2000 , the average concentration ratio was a high 0.85 , and this decreased to only 0.83 in 2009 (in each case excluding three members for which data is not available for the specific year). 
While two members had a concentration ratio of one in 2000 , this deteriorated to five members in 2009. In only five of the fourteen member countries were there noticeable increases in the level of competition in the banking sector in the period 2000 to 2009, although increased competitiveness was generally high on SADC governments' agendas to open up access to banking and/or identified by the IMF as important (see e.g. CBL, 2004:5; MFNP, 2004:67; IMF, 2006:23; IMF, 2008d:42; IMF, 2010b:14).

TABLE 7: Bank concentration ${ }^{1}$

\begin{tabular}{|c|c|c|}
\hline Country & 2000 & 2009 \\
\hline Angola & 1 & 0.65 \\
\hline Botswana & 0.94 & 0.7 \\
\hline Lesotho & 1 & $1 * \star$ \\
\hline Madagascar & 0.74 & 1 \\
\hline Malawi & 0.9 & 1 \\
\hline Mauritius & 0.84 & 0.75 \\
\hline Mozambique & 0.75 & 1 \\
\hline Namibia & $0.91^{\star}$ & 1 \\
\hline Seychelles & $0.93 \star \star$ & $0.94 * \star \star$ \\
\hline South Africa & 0.85 & 0.81 \\
\hline Swaziland & 0.92 & 1 \\
\hline Tanzania & $0.64 \star$ & 0.47 \\
\hline Zambia & 0.66 & 0.74 \\
\hline Zimbabwe & 0.73 & $1 * \star \star$ \\
\hline
\end{tabular}

Source: World Bank, 2009.

$\star 2004 ; \star \star 2005 ; * \star \star 2006$

1 Assets of 3 largest banks as share of assets of all commercial banks

To increase competition, member governments attempted a number of strategies. Lesotho, Namibia, Mozambique, South Africa and Zambia explored the possibility of enticing new institutions to enter the banking sphere. Lesotho adapted its banking regulations to allow branches of foreign banks (CBL, 2004). Unfortunately this had the result merely of expanding the choice of services for urban clients, as these branches were not located in the rural areas where the poor are concentrated (CBL, 2007:2). Research on foreign bank entry in Namibia found that it had not necessarily resulted in more efficient or competitive financial markets (Okeahalam, 2008:960). The five member countries in question all investigated the development of second tier banks to focus on the unbanked market (CBL, 2007:3; BoN, 2005; Schoombee, 2009:153-155; MFNP, 2004). These banks typically have lower capital and prudential requirements than traditional first-tier commercial banks, thus creating the opportunity for new entities to enter the market and provide their services at competitive prices. The Bank of Namibia's research concluded that second-tier banks were not the answer to more competition and increased access for the poor, but nevertheless decided to draft legislation to allow second-tier 
(microfinance) banks (BoN, 2010:163) and granted the first microfinance-oriented bank licence in 2009 (BoN, 2009:157). In Mozambique, 6.2\% of the banked in 2009 had a bank account with microfinance (second-tier) banks (FinMark Trust, 2009b:42). Lesotho, South Africa and Zambia made little or no progress in this regard. By 2009, none of these countries had issued licences for second-tier banks.

Increased transparency is a further strategy to contribute to a competitive banking environment. In SADC, a total of ten members had disclosure requirements in respect of effective interest rates and/or fees, and seven members a 'plain language' requirement for financial products and/or contracts (see TABLE 6 earlier in the paper). The latter requirement is crucial in an environment of low financial literacy, generally the situation in SADC countries. In Mozambique, for example, $49 \%$ of rural adults do not know what a bank is (FinMark Trust, 2009b:32).

Transparency was proposed by the IMF to enhance competition in banking in Malawi (IMF, 2007), Mozambique (IMF, 2010:18) and Namibia (IMF, 2006:23). In the Malawi government's 2008 Letter of Intent (IMF, 2008e) in response to the IMF's financial system stability assessment, it was reported that information disclosure clauses had been introduced in the lending contracts of banks. In the case of Mozambique, the IMF's 2009 Financial Sector Assessment Programme update identified the publishing of fee information as an important measure to solve some of the problems that inhibited progress in access to banking. Likewise, the IMF also recommended this approach to the Namibian government, but in 2010 the Bank of Namibia noted that bank fees were still complicated and that transparency was only then to become a key focus of the Bank (BoN, 2010:165). Transparency was also the method suggested in the Zambian government's Financial Sector Development Plan for 2004-2009 (MFNP, 2004) to protect customers from excessive bank charges that were partly a result of the difficulty customers experienced in comparing such charges. The Bank of Zambia reported in 2008 that this proposal had been implemented and that bank charges were published on a quarterly basis in the daily newspapers (Kalyalya, 2008:9).

The distance to travel to a bank branch has cost implications, namely transportation cost and opportunity cost (travelling time) and therefore impacts on the affordability of banking services. A competitive environment is expected to contribute to decreasing the distance to bank access points. Governments' branching regulations (see TABLE 8), though, may impede banks from opening new branches: formal approval from the supervisor of banks is required for each new branch in ten SADC members, and in six member countries the minimum number of days per week a branch has to operate is prescribed. Exemption from branching regulations may of course encourage new branches. One such an exemption applies, but in only three SADC countries (see TABLE 8), namely from strict security requirements for branches in poor areas. The central bank of Namibia, in a 2004 occasional paper, proposed that the Banking Institutions Act be amended as follows to encourage the opening of branches in unbanked rural areas (Kaagunga et al., 2004:2): require a new rural branch when banks are given permission to shut down non-profitable branches with no strings attached in overbanked areas, or when a new branch is established in an urban area. This proposal fortunately did not come to fruition. A similar proposal was considered in Tanzania, but the IMF (2003:32) strongly advised against this. 
TABLE 8: Government policies and regulations regarding bank access points, 2009

\begin{tabular}{|c|c|c|c|c|c|c|}
\hline Country & $\begin{array}{c}\text { Supervisor } \\
\text { approval } \\
\text { needed to } \\
\text { open new } \\
\text { branch }\end{array}$ & $\begin{array}{l}\text { Branch to } \\
\text { operate } \\
\text { minimum } \\
\text { number of } \\
\text { days/week }\end{array}$ & $\begin{array}{l}\text { Exemptions } \\
\text { from } \\
\text { require- } \\
\text { ments of } \\
\text { bank } \\
\text { security for } \\
\text { poor areas }\end{array}$ & $\begin{array}{l}\text { Mobile } \\
\text { branches } \\
\text { and/or } \\
\text { branchless } \\
\text { banking } \\
\text { allowed }\end{array}$ & $\begin{array}{c}\text { Banks may } \\
\text { provide } \\
\text { services at } \\
\text { post offices }\end{array}$ & $\begin{array}{c}\text { Banks can } \\
\text { formally } \\
\text { contract } \\
\text { companies } \\
\text { as banking } \\
\text { agents }\end{array}$ \\
\hline \multicolumn{7}{|l|}{ Angola } \\
\hline Botswana & $x$ & $x$ & & $x$ & & \\
\hline \multicolumn{7}{|l|}{ DRC } \\
\hline Lesotho & $x$ & & & $x$ & & $x$ \\
\hline Madagascar & & & & $x$ & & $x$ \\
\hline Malawi & $x$ & & $x$ & $x$ & $x$ & \\
\hline Mauritius & $x$ & $x$ & & $x$ & $x$ & $x$ \\
\hline Mozambique & $x$ & & & $x$ & & \\
\hline Namibia & $x$ & $x$ & $x$ & & & \\
\hline South Africa & & & & $x$ & & $x$ \\
\hline Swaziland & $x$ & & & & $x$ & \\
\hline Tanzania & $x$ & $x$ & & $x$ & & $x$ \\
\hline Zambia & $x$ & $x$ & & $x$ & & \\
\hline Zimbabwe & $x$ & $x$ & $x$ & $x$ & & \\
\hline
\end{tabular}

Sources: CGAP et al., $2009 \& 2010$

Allowing mobile branches and/or branchless banking (e.g. ATMs) creates the opportunity for banks to deliver services cost-effectively in sparsely populated rural areas and also limits the client's cost associated with having to travel far to gain access to a bank. Banking regulations in ten SADC countries permit this (see TABLE 8), a positive development. Contracting companies as banking agents serves the same purpose, but to protect the consumer, their services need to be regulated and are usually restricted to payment-related functions (CGAP et al., 2009:43). Only five SADC members allow banking agents (see TABLE 8). Utilising post offices as banking agents has enormous potential, as their numbers are double those of bank branches in the developing world (CGAP et al., 2009:47). Regrettably, only three SADC countries permit this (see TABLE 8).

\subsection{Financial literacy}

It was mentioned above that financial illiteracy is generally a problem in all SADC countries (also refer to TABLE 3). Six member countries planned to specifically address this issue towards the end of the period of study (see TABLE 6 earlier in the paper). In Namibia it was identified by the central bank as a major stumbling block in achieving financial inclusion, a strategic objective of the Bank of Namibia (BoN, 2010:163-164). Evidence of the importance accorded to financial literacy is the establishment in 2009 of the Namibia Financial Literacy Working Group. 
The government, Bank of Namibia, Namibia Competition Commission and Namibia Consumer Trust were some of the members, and the intention was to broaden the membership to also include industry. A policy framework and plan of action were drawn up. In Tanzania, the central bank, with the support of the Minister of Finance, took the lead in developing a national financial literacy strategy. The first workshop to this end was held in June 2009 (FSDT, 2009). In Zambia, the Financial Sector Development Plan for 2004-2009 recommended that bank clients ought to be educated to enable switching between banks in search of reduced costs (MFNP, 2004:67). This apparently did not materialise, as evidenced by the Zambian central bank's expressed intent in 2009 to develop and implement a strategy to increase the level of financial literacy (FinMark Trust, 2009d).

\subsection{Legal infrastructure}

An inadequate legal infrastructure, specifically with regard to land ownership and land transfer rights as well as contract enforcement procedures, creates serious barriers to access bank credit. Problems with land ownership and land transfer rights limit the availability of suitable collateral, and ineffective contract enforcement procedures deter banks from providing credit. This barrier appears to be of vital importance in a number of SADC economies judging from the attention it has received both from the governments in question and the IMF.

In a 2004 country report on Lesotho, the IMF (2004:32-40) reviewed the then poor financial intermediation situation and the measures that had previously been taken by the Lesotho government to boost financial intermediation. The weak legal infrastructure was highlighted and specific reference made to ill-defined property rights that virtually precluded the use of land as collateral, contract enforcement problems due to an inefficient and sluggish judicial system, and the disqualification from access to credit for women without their spouse's written consent. Although legislation was adopted in 2006 to address the equality of both spouses to contract legally and permit the use of land as collateral, steps taken to simplify the process of issuing titles for land, and procedures expedited to transfer property rights (see also CBL, 2007:2), the IMF still identified the lack of collateralisation of land as problematic in 2008 (IMF, 2010a:14). This conclusion is supported by the Central Bank of Lesotho's survey on demand and supply of bank credit that found that lack of adequate collateral was the most important grounds banks had for rejecting a loan application (CBL, 2009:22).

The IMF's 2003 Financial Sector Assessment program (FSAP) of Mozambique identified a number of obstacles in the bank lending environment, including problems in the legal framework, and recommended certain steps to rectify it. The majority of these recommendations were fully or partially implemented by 2009, including the modernisation of the Notary Office and the Public Commercial Registry, and the establishment of a specialised commercial court (IMF, 2010b:7). Nevertheless, obstacles remained in the legal framework that contributed to the unsatisfactory situation of the majority of the population still lacking access to financial services, and consequently these barriers were addressed and included in the key recommendations of the IMF's 2009 FSAP update (IMF, 2010b:8). The barriers in question included slow and expensive contract enforcement procedures inhibiting the debt recovery process, and a poorly functioning property registry with less than $30 \%$ of properties registered (IMF, 2010b:14).

The situation in Tanzania was analogous to that experienced in Lesotho and Mozambique and had already been alluded to by the IMF in 2003 (IMF, 2003). Similarly, in an address at the central bank conference on the future of rural finance in Tanzania, the country's Ministry of Finance (Khijjah, 2004:3,5) acknowledged the problems related to land titling and indicated 
that the government had already begun to implement a programme to formalise property rights. The government also undertook to improve the legal framework in order to boost the poor credit repayment culture (Khijjah, 2004:9). The IMF reported in 2007 and 2008 that reforms in both these areas were ongoing (IMF, 2007a:47; IMF, 2008c:33-34) and in 2010 still indicated that poor creditor rights inhibited access to credit (IMF, 2010c:11).

In Zambia, the government's Financial Sector Development Plan 2004-2009 alludes to the general perception of a lack of intent to take legal action against financial crimes, the latter including the deliberate decision not to repay loans. This Plan consequently recommended increasing the capacity of the commercial courts to enable the speedy prosecution of financial crimes (MFNP, 2004:64,67). There were apparently also problems with the valuation of property to be lodged as collateral. The recommendation in this regard was that all surveyors of property pledged as collateral should be approved by the central bank of Zambia (MFNP, 2004:67). Though the registration of title deeds of land was not identified as a problem in this Plan, the 2009 FinScope survey found that it in fact appears to be. In the region of $87 \%$ of those who stated that they owned a house did not have the title deeds (FinMark Trust, 2009d).

In Swaziland, private ownership of land was severely restricted and was identified by the IMF (2008b:40) as a key constraint to access bank credit (due to its unavailability as collateral).

\subsection{Credit history}

When considering loan applications, banks need access to the applicant's credit history. A lack of such history poses a serious constraint on banks in their decision-making process and substantially increases the screening costs, would often lead to a negative result or high cost for the borrower. This consequently acts as a barrier for the potential customer to access bank credit. A credit bureau typically provides the required information and if there is no such institution it is problematic, as experienced in a number of SADC countries.

The IMF already mentioned the lack of credit history in 2004 as one reason for the low access to banking in Lesotho (IMF, 2004). Apparently the Central Bank of Lesotho wanted to commence with the establishment of a credit bureau in 2003, but due to the private sector's negative response, it decided to rather launch a credit information register for the banks within the central bank (CBL, 2005:30). This was found to be too expensive and it subsequently elected to back the government's initiative to launch a public national credit bureau (CBL, 2006:27). In 2009, the process of creating such a credit bureau was still ongoing (CBL, 2009:20).

The Malawi government, as part of a plan to support financial intermediation in that country, agreed to improve creditor rights as well as the accessibility of information in credit markets (IMF, 2007b:20). In 2008 it reported in its Letter of Intent to the IMF (2008e:5) that it had progressed in this regard, having commenced the process to launch credit bureaus.

Mozambique, in contrast to Lesotho and Malawi, already had a credit bureau in the 2000s. But it was situated within the central bank and hence was used more as a monitoring device for prudential purposes. With this narrow focus, it was decided in 2009 to look into the legality of establishing private credit bureaus that would collect a broader range of information suitable for screening loan applicants (IMF, 2010b:14).

It was reported in 2003 that Tanzania did not have a credit bureau; this prompted the central bank to take the initiative and create an obligatory credit reporting system to which all licensed lenders would have to belong (IMF, 2003:30). By 2005 a credit rating agency had been 
established and by March 2007 a new credit information system planned by the central bank was presented to government for its endorsement (IMF, 2007a:14,46). Following its approval, the process to launch the credit information databank got underway but did not meet the end-June 2008 deadline (IMF, 2008c:34).

In Zambia, the absence of a credit bureau was noted in the country's Financial Sector Development Plan 2004-2009 as the cause of a weak credit culture: defaulting on a loan had no impact on the borrower's credit standing at a different institution and thus discouraged a sound repayment ethic (MFNP, 2004:63). In the same Plan the government mentioned that it was in the process of founding a credit bureau, which came to fruition with its launch in January 2007. Two years later the central bank was not yet pleased with the functioning of the credit bureau, however (BoZ, 2008:54). The supply of data to the bureau and the level of use by financial institutions were still low, indicating that the mere existence of such an institution does not imply success.

\subsection{Financial inclusion policies}

While the above policies were all formulated to bridge specific barriers the poor experienced in accessing and using formal banking services, there were also policies that aimed to directly result in financial inclusion. In this regard, Kendall et al. (2010), researching bank access in 139 countries, found that policies specifically focused on financial inclusion did not have a significant impact on deposit and loan account penetration. They noted, however, that this '... does not imply that these policies are ineffective, but rather an indicator of the large variations (in) the countries pursuing them' (Kendall et al., 2010:4).

In eight SADC members their governments in 2009 either encouraged or had reforms in progress to encourage the recipients of government transfers (including pension payments, child allowances, and unemployment insurance) to open bank accounts (see TABLE 6 earlier in the paper). Likewise, in four SADC countries either banks were required to offer basic bank accounts in 2009 , low cost being the attraction for the customer, or reforms were in progress to require the offering of such accounts. This includes South Africa, where basic bank accounts were not a formal requirement, but offered by banks because of moral suasion by government.

Such inclusion policies, however, will be successful in the SADC region only ' $\ldots$ if participating financial institutions see them as a viable business proposition and if they address a binding constraint, be it cost or distance' (CGAP et al., 2009:2). Recipients of government transfers will open bank accounts only if these are easily accessible and costs are low. Basic bank accounts (typically featuring a combination of no or low fees, no or low minimum amount requirements, and limited free ATM transactions) will be supported by the poor only if the poor are financially literate, if these accounts are easily accessible and provide the combination of banking services the poor require. For their part, banks will willingly provide basic accounts only if this makes commercial sense. This does not necessarily imply that the basic bank product must in itself be profitable, which is expected often not to be the case, but it should create the opportunity for the bank to draw basic bank customers into higher-yielding banking products in time.

As was indicated earlier, the considerable success achieved in increasing the use of banking services in South Africa can be directly attributed to the take-up of the Mzansi basic bank account offered by the four major commercial banks and the government-owned Postbank. Although the commercial banks 'willingly' created this product, the moral suasion by government had been instrumental in their decision. The banks realised that the Mzansi product 
in itself would most probably not be profitable and bargained on Mzansi account holders migrating to more lucrative products in time. This apparently had not yet materialised to the desired extent (Schoombee, 2009:153). In addition to the moral suasion, CGAP et al. (2009:20) also mentioned two other characteristics that explain the high take-up of Mzansi accounts, namely the existence of a well-developed banking infrastructure boasting an abundance of access points, and a significant potential demand for basic banking products if available at low cost.

\section{CONCLUSION}

With the limited availability of comparative data, only tentative conclusions are possible regarding the gains made in increasing the access to and use of formal banking services in SADC in the period 2000-2009, as well as to the policies that made a significant impact on achieving greater access and use. As is to be expected, the four most banked SADC economies also have the greatest access to banking and represent four of the five most developed (higher-middleincome) countries in this grouping. The increase in access as measured by ATMs per $1000 \mathrm{~km}^{2}$ was significant in all seven SADC countries for which this data is available, the median growth rate being $67 \%$ over the period $2003 / 4$ to 2009 . This was a very encouraging development and is expected to have had a considerable positive impact on the use of banking services. In the two countries (of only three for which data is available) that had experienced significant growth in bank usage, South Africa by $33 \%$ and Tanzania by $21 \%$, their increase in access was considerably higher than the median of $67 \%$ - South Africa grew by $125 \%$ and Tanzania by $800 \%$.

Affordability appears to have been the major impediment to greater use of banking services. Given the low level of development of most SADC economies, it was not surprising that lack of income was identified by the unbanked as the most significant access barrier. Government policies to attain a higher level of development in their countries would thus also impact positively on affordability and access to banking, but given the general nature of such policies, were not addressed in this research. The focus was rather on those policies that attempted to reduce the high cost of banking services in order to make banking more affordable.

Most SADC members highlighted the lack of competition in the banking sector as key to the high cost customers had to face when transacting with banks. Various policies were considered and/or implemented to enhance competition, including allowing second-tier banks, requiring increased transparency in banks' dealings with their customers, and policies to encourage banks to bring banking closer to their clients/potential clients (e.g. mobile banking, branchless banking). Using the bank concentration ratio as an indication of competitiveness, little if any progress was made in SADC as a whole, although a small number of individual countries had lowered their bank concentration ratios.

No firm conclusions are possible with regard to the success of the range of policies employed by $S A D C$ governments to increase access to and use of formal banking services in their respective countries. In principle, all policies aimed at lifting the barriers to banking, either from the potential customer's perspective (e.g. lower cost, financial literacy) or from the bank's perspective (e.g. adequate legal infrastructure, access to a credit bureau) should have had a positive impact. The basic bank (Mzansi) account initiative in South Africa, as reported previously, was very successful in reaching the poor with banking services. On the evidence available, no other successes on this scale were achieved in the rest of the SADC. 


\section{LIST OF REFERENCES}

Beck, T. (2006). Creating an efficient financial system: challenges in a global economy. (World Bank Policy Research Working Paper No. 3856).

Beck, T., Demirgüç-Kunt, A. \& Peria, M.S.M. (2007). Reaching out: Access to and use of banking services across countries. Journal of Financial Economics, 85: 234-266.

Beck, T., Demirgüç-Kunt, A. \& Peria, M.S.M. (2008). Banking services for everyone? Barriers to bank access and use around the world. World Bank Economic Review, 22(3), pp. 397-430.

Beck, T. \& Brown, M. (2011). Which households use banks? Evidence from the transition economies. (Swiss National Bank Working Paper No. 2011-1).

BoN (Bank of Namibia) (2005). Annual Report. [On-line] Available: https://www.bon.com.na/. (Accessed 17 July 2011).

BoN (2009). Annual Report. [0n-line] Available: https://www.bon.com.na/. (Accessed 17 July 2011).

BoN (2010). Annual Report. [0n-line] Available: https://www.bon.com.na/. (Accessed 17 July 2011).

BoZ (Bank of Zambia) (2008). Annual Report. [On-line] Available: http://www.boz.zm/. (Accessed 27 July 2011).

Caskey, J., Duran, C.R. \& Solo, T.M. (2006). The urban unbanked in Mexico and the United States. (World Bank Policy Research Working Paper No. 3835).

CBL (Central Bank of Lesotho) (2004). Supervision Department Annual Report. [On-line] Available: www.centralbank.org.ls/. (Accessed 19 July 2011).

CBL (2005). Supervision Department Annual Report. [0n-line] Available: www.centralbank.org.ls/. (Accessed 19 July 2011).

CBL (2006). Supervision Department Annual Report. [0n-line] Available: www.centralbank.org.Is/. (Accessed 19 July 2011).

CBL (2007). Annual Report. [On-line] Available: www.centralbank.org.ls/. (Accessed 19 July 2011).

CBL (2009). Annual Report. [On-line] Available: www.centralbank.org.Is/. (Accessed 19 July 2011).

CGAP (Consultative Group to Assist the Poor) and World Bank (2009). Financial Access 2009. Washington, DC: CGAP and World Bank.

CGAP and World Bank (2010). Financial Access 2010. Washington, DC: CGAP and World Bank.

Dupas, P. \& Robinson, J. (2009). Savings constraints and microenterprise development: Evidence from a field experiment in Kenya. (NBER Working Paper No. 14693).

FinMark Trust (2004). FinScope Namibia 2004. [Online] Available:

http://www.finmark.org.za/finscope/publications/ (Accessed l July 2011).

FinMark Trust (2005). FinScope Zambia 2005. [Online] Available:

http://www.finmark.org.za/finscope/publications/ (Accessed l July 2011).

FinMark Trust (2006) FinScope Tanzania 2006. [Online] Available:

http://www.finmark.org.za/finscope/publications/ (Accessed 2 July 2011).

FinMark Trust (2007). FinScope Namibia 2007. [Online] Available:

http://www.finmark.org.za/finscope/publications/ (Accessed l July 2011). 
FinMark Trust (2008). FinScope Malawi 2008. [Online] Available:

http://www.finmark.org.za/finscope/publications/ (Accessed 2 July 2011).

FinMark Trust (2009a). FinScope Botswana 2009. [Online] Available: http://www.finmark.org.za/wpcontent/uploads/pubs/Rep_FinScope_Botswana_2009.pdf (Accessed l July 2011).

FinMark Trust (2009b). FinScope Mozambique 2009. [Online] Available:

http://www.finmark.org.za/blog/publication/brochure-finscope-mozambique-2009/ (Accessed 2 July 2011).

FinMark Trust (2009c). FinScope Tanzania 2009. [Online] Available:

http://www.finmark.org.za/finscope/publications/ (Accessed 2 July 2011).

FinMark Trust (2009d). FinScope Zambia 2009. [Online] Available:

http://www.finmark.org.za/blog/publication/finscope-zambia-2009-presentation-of-top-line-

findings/ (Accessed l July 2011)

FinMark Trust (2010). FinScope South Africa 2010. [Online] Available:

http://www.finmark.org.za/wp-content/uploads/pubs/FinScope-2010_Brochure2.pdf (Accessed 2 July 2011).

FSDT (Financial Sector Deepening Trust) (2006). FinScope E-Book Tanzania.

FSDT (2009). Financial Literacy Strategy.

Honohan, P.\& King, M. (2009). Cause and effect of financial access: Cross-country evidence from the FinScope surveys. Paper prepared for the World Bank Conference "Measurement, Promotion, and Impact of Access to Financial Services", Washington DC, March 12-13.

IMF (International Monetary Fund) (2003). IMF Country Report No. 03/241 (Tanzania). [Online] Available: http://www.imf.org/external/publications/ (Accessed 16 August 2011)

IMF (2004). IMF Country Report No. 04/23 (Lesotho). [Online] Available: http://www.imf.org/external/publications/ (Accessed 17 August 2011)

IMF (2006). IMF Country Report No. 06/152 (Namibia). [Online] Available: http://www.imf.org/external/publications/ (Accessed 16 August 2011)

IMF (2007a). IMF Country Report No. 07/138 (Tanzania). [Online] Available: http://www.imf.org/external/publications/ (Accessed 16 August 2011)

IMF (2007b). IMF Country Report No. 07/147 (Malawi). [Online] Available:

http://www.imf.org/external/publications/ (Accessed 19 August 2011)

IMF (2008a). IMF Country Report No. 08/58 (Botswana). [Online] Available: http://www.imf.org/external/publications/ (Accessed 20 August 2011)

IMF (2008b). IMF Country Report No. 08/86 (Swaziland). [Online] Available: http://www.imf.org/external/publications/ (Accessed 19 August 2011)

IMF (2008c). IMF Country Report No. 08/178 (Tanzania). [Online] Available: http://www.imf.org/external/publications/ (Accessed 16 August 2011)

IMF (2008d). IMF Country Report No. 08/353 (Kenya, Uganda \& Tanzania). [Online] Available: http://www.imf.org/external/publications/ (Accessed 16 August 2011)

IMF (2008e). Malawi: Letter of Intent. 
IMF (2010a). IMF Country Report No. 10/5 (Lesotho). [Online] Available: http://www.imf.org/external/publications/ (Accessed 17 August 2011)

IMF (2010b). IMF Country Report No. 10/12 (Mozambique). [Online] Available: http://www.imf.org/external/publications/ (Accessed 22 August 2011)

IMF (2010c). IMF Country Report No. 10/177 (Tanzania). [Online] Available: http://www.imf.org/external/publications/ (Accessed 16 August 2011)

Kaagunga, E., Zaaruka, B.P., Motinga, E. \& Steytler, J. (2004). Viability of commercial bank branches in rural communities in Namibia. (Bank of Namibia Occasional Paper No. 2/2004).

Kalayalya, D.H. (2008). Financial access and sustainability of financial services in Zambia. Paper presented by the deputy governor, Bank of Zambia at the Zambia Institute of Chartered Accountants Annual Business Conference, 7-8 August, Livingstone, Zambia.

Kendall, J., Mylenko, N. \& Ponce, A. (2010). Measuring financial access around the world. (World Bank Policy Research Working Paper No. 5253).

Khijjah, R.M. (2004). The role of government in building sustainable rural financial markets. Presentation at the $3^{\text {rd }}$ Bank of Tanzania Annual Conference on the Future of Rural Finance in Tanzania, 15-17 March, Arusha, Tanzania.

MFNP (Ministry of Finance and National Planning) (2004). Financial Sector Development Plan for Zambia 2004-2009. Republic of Zambia.

Okeahalam, C.C. (2008). Internationalisation and firm performance: Evidence from estimates of efficiency in banking in Namibia and Tanzania. Journal of International Development, 20, pp. 942964.

SADC (Southern African Development Community) 2008. Regional Indicative Strategic Development Plan. [On-line] Available: http://www.sadc.int/index/browse/page/106. (Accessed 17 July 2011).

Schoombee, A. (2009). Access to formal financial services for South Africa's poor: Developments since 1990. South African Journal of Economic History, 24(2), pp. 131-156.

World Bank 2009. World Bank Financial Structure Database. [0n-line] Available: http://www.worldbank.org/. (Accessed 10 August 2011).

World Bank 2011. World Development Indicators 2011. Washington, DC: World Bank. 
